\title{
IMPLIKASI PENGGUNAAN INFORMASI AKUNTANSI DALAM PENGAMBILAN KEPUTUSAN MELALUI VARIABEL PENGETAHUAN AKUNTANSI, KEPRIBADIAN WIRAUSAHA DAN UMUR USAHA
}

\author{
Fitrih Helmiyati ${ }^{1}$, Diyah Probowulan ${ }^{2}$, Retno Murwanti $^{3}$ \\ Universitas Muhammadiyah Jember ${ }^{1,2,3}$ \\ fitri.helmiyati27@ gmail.com ${ }^{1}$
}

\begin{abstract}
ABSTRAK
Tujuan penelitian ini adalah untuk menganalisis pengaruh pengetahuan akuntansi, kepribadian wirausaha dan umur usaha terhadap penggunaan informasi akuntansi dalam pengambilan keputusan investasi di UMKM di Kecamatan Kaliwates Kabupaten Jember. Penelitian ini termasuk explanatory research. Teknik pengambilan sampel dilakukan menggunakan teknik convenience sampling, yaitu pengambilan sampel didasarkan pada ketersediaan elemen dan kemudahan mendapatkannya. Metode analisis data yang digunakan adalah analisis regresi linier berganda. Hasil penelitian menunjukkan bahwa secara parsial variabel pengetahuan akuntansi, kepribadian wirausaha dan umur usaha berpengaruh signifikan terhadap penggunaan informasi akuntansi dalam pengambilan keputusan investasi pada UMKM di Kabupaten Kaliwates Kabupaten Jember. Simpulan, semua variabel yang diamati dalam penelitian ini menunjukkan adanya pengaruh terhadap pengambilan keputusan investasi pada UMKM di Kabupaten Kaliwates Jember. Semakin baik variabel-variabel tersebut maka penggunaan informasi akuntansi dalam pengambilan keputusan investasi akan semakin meningkat.
\end{abstract}

Kata Kunci: Kepribadian Wirausaha, Pengambilan Keputusan Investasi, Pengetahuan Akuntansi, UMKM Kaliwates Jember, Umur Usaha

\section{ABSTRACT}

The purpose of this study was to analyze the effect of accounting knowledge, entrepreneurial personality and age of business on the use of accounting information in making investment decisions in UMKMadi, Kaliwates Jember District. This research is included in the explanatory research. Sampling techniques were carried out using convenience sampling techniques, namely sampling based on the availability of elements and the ease of obtaining them. The data analysis method used was multiple linear regression analysis. The results show that partially the variables of accounting knowledge, entrepreneurial personality and business age have a significant effect on the use of accounting information in making investment decisions on SMEs in Kaliwates Jember District. In conclusion, all the variables observed in this study indicate an influence on investment decision making at UMKM in Kaliwates Jember District. The better these variables are, the more the use of accounting information in making investment decisions will increase.

Keywords: Entrepreneurial Personality, Investment Decision Making, Accounting Knowledge, UMKM Kaliwates Jember, Business Age 


\section{PENDAHULUAN}

Pembangunan nasional memiliki tujuan untuk mewujudkan masyarakat adil dan makmur secara merata. Pencapaian tujuan ini perlu didukung dengan sinergi antara pemerintah yang senantiasa perlu memaksimalkan pemanfaatan sumber daya serta potensi yang dimiliki Negara Indonesia dan masyarakat sebagai pelaku ekonomi. Pembangunan nasional di Indonesia didukung dengan perkembangan ekonomi yang berbasis pada ekonomi kerakyatan. Hal ini ditunjukan dengan kontribusi sektor Usaha Mikro, Kecil dan Menengah (UMKM) terhadap Produk Domestik Bruto (PDB) yang mencapai 60,34 persen. UMKM juga berperan dalam penyerapan tenaga kerja serta berperan dalam mendistribusikan hasil-hasil pembangunan. Menurut Bank Indonesia dan LPPI (2015), sektor UMKM memiliki peran penting dalam perekonomian di Indonesia, UMKM memiliki proporsi sebesar 99,99\% dari total keseluruhan pelaku usaha di Indonesia. UMKM mampu membuktikan eksistensinya dalam perekonomian Indonesia karena mayoritas usaha berskala kecil tidak terlalu bergantung pada modal besar atau pinjaman dalam mata uang asing. Jumlah unit UMKM di Indonesia mengalami peningkatan setiap tahunnya. Pada tahun 2019, diprediksi jumlah sektor UMKM di Indonesia terus meningkat. Untuk menguatkan pondasi ekonomi Negara Indonesia, UMKM harus selalu ditingkatkan, bukan hanya pada usaha mikro melainkan pula usaha kecil dan menengah.

Era modern saat ini, informasi akuntasi mempunyai pengaruh sangat penting untuk mencapai keberhasilan dalam menjalankan bisnis UMKM. Menurut Susanto (2017) sistem informasi akuntansi adalah kumpulan atau integrasi dari sub-sub sistem atau komponen baik fisik maupun nonfisik yang saling berhubungan dan bekerja sama satu dengan lain secara harmonis untuk mengolah data transaksi yang berkaitan dengan masalah keuangan menjadi informasi keuangan. Sistem informasi akuntansi merupakan sistem yang mengumpulkan, mencatat, menyimpan dan memproses data sehingga menghasilkan informasi untuk pengambilan keputusan.

Informasi akuntansi sangat diperlukan untuk memahami situasi keuangan dalam bisnis, bukan hanya sebagai informasi dalam bentuk angka mengenai hal yang berkaitan dengan ekonomi namun menjadi informasi yang sangat bermakna untuk meningkatkan kemampuan pelaku bisnis UMKM untuk meningkatkan pemahaman dan kepercayaan pengguna dalam penentuan keputusan investasi (Sari \& Dwirandra, 2015). Bagi 
wirausaha, penggunaan informasi akuntansi untuk melakukan pengambilan keputusan investasi sangat perlu diprioritaskan untuk keberlangsungan bisnis yang dijalankan.

Kenyataan yang terjadi di dalam masyarakat yang memiliki usaha UMKM belum memanfaatkan informasi akuntansi dalam pengelolaan usahanya terutama dalam pengambilan keputusan investasi. Menurut Astiani \& Sugoro (2017) salah satu permasalahan yang masih dihadapi UMKM adalah permasalahan dalam menyelenggarakan dan memanfaatkan informasi akuntansi dalam pengelolaan usahanya. Jika dilihat dari segi pertumbuhannya, usaha kecil mengalami masalah yang timbul pada tahap-tahap yang serupa, ini disebabkan perusahaan tidak memiliki informasi, baik dari dalam usaha maupun dari luar usaha. Salah satu sistem informasi memberikan informasi yang dibutuhkan adalah sistem informasi akuntansi.

Ketidakmampuan dalam bidang akuntansi menjadi faktor utama yang menimbulkan masalah dan mengakibatkan kegagalan perusahaan kecil dan menengah dalam membangun usaha. Hal ini memberikan indikasi bahwa perusahaan dalam melaporkan keuangan berdasarkan kebutuhannya saja dan perusahaan cenderung tidak melaporkan secara kontinyu. Pencatatan keuangan secara akuntansi dianggap terlalu rumit untuk dilakukan dalam berskala kecil seperti UMKM karena siklus usaha pada UMKM yang sederhana. Hal ini menunjukan bahwaperlu adanya dorongan bagi pelaku UMKM untuk menggunakan bisnis informasi akuntansi dengan dilakukan pemetaan pengetahuan yang mereka miliki. Pengetahuan akuntansi yang baik akan menjadikan para pelaku bisnis UMKM mampu memahami serta memanfaatkan informasi akuntansi sehingga dapat dipergunakan dalam pembuatan keputusan investasi, sebaliknya para pelaku bisnis yang belum mempunyai pengetahuan akuntansi yang baik maka belum dapat memanfaatkan informasi akuntansi (Juniariani \& Wirakusuma, 2016).

Peningkatan UMKM di Indonesia menjadi salah satu bukti bahwa dunia wirausaha mulai diminati oleh sebagian masyarakat di Indonesia. Menurut Handar (2017) pemberdayaan UMKM sangat penting untuk mendorong pengembangan jiwa kewirausahaan masyarakat, maju-mundur serta berkembangnya UMKM adalah mutlak karena keinginan dan motivasi dari masyarakat sebagai pelaku usaha tersebut dengan mengubah pola berfikir usaha sekedar menutupi kebutuhan berubah menjadi seorang wirausaha atau entrepreneur. Pelaku UMKM yang memiliki kepribadian wirausaha yang baik akan dapat lebih mempertahankan bisnisnya dan dapat menjadi inspirasi 
masyarakat lain untuk menjadi wirausaha yang tangguh. Menurut Putra (2018) kepribadian kewirausahaan merupakan kemampuan seseorang untuk mencapai persyaratan dalam berwirausaha yang efektif dalam suatu usaha ataupun bisnis. Sikap dan perilaku seorang wirausaha juga berperan penting untuk perusahaan dalam berbagai skala usaha untuk mecapai keberhasilan dalam lingkungan yang kompetitif. Wirausaha yang memiliki kepribadian baik cenderung melakukan persaingan bisnis dengan cara yang berbeda termasuk dalam penggunaan informasi akuntansi dengan tujuan pengambilan keputusan investasi. Cara pandang seorang wirausaha yang berkepribadian baik cenderung lebih prospektif dalam mengembangkan usaha. Seseorang yang memiliki kepribadian kewirausahaan yang baik akan mampu meningkatkan kepemimpinannya dalam mengambil resiko dan pengambilan keputusan serta meningkatkan kinerja manajerialnya. Maisaroh (2018) menyatakan bahwa kepribadian berwirausaha dipengaruhi oleh beberapa faktor salah satunya adalah pengalaman hidup yang dijalani seseorang. Semakin banyak aktifitas atau pengalaman seseorang dalam berorganisasi dan semakin tinggi pengalaman kerja maka kepribadian berwirausaha pada sektor UMKM akan semakin tinggi. Orang yang memiliki pengalaman sebelumnya dalam berwirausaha akan memiliki minat lebih besar dalam mengembangkan usahanya dibandingkan orang yang belum memiliki pengalaman dalam berwirausaha serta lebih mampu memanfaatkan berbagai informasi untuk menentukan keputusan yang akan dilakukan berkaitan dengan usaha yang dijalankannya.

Selain pengetahuan akuntansi dan kepribadian wirausaha, umur perusahaan juga mempengaruhi pengambilan keputusan oleh pemilik UMKM. Menurut Asih (2018) umur perusahaan merupakan berapa lamanya perusahaan yang dimaksud berdiri dan beroperasi, semakin lama suatu perusahaan beroperasi maka kebutuhan akan suatu informasi akan semakin kompleks. Hal ini disebabkan oleh tuntutan dari perkembangan yang dialami oleh perusahaan. Umur perusahaan juga akan mempengaruhi tingkat penggunaan informasi akuntansi pada suatu usaha yang didirikan, perusahaan yang memiliki usia lebih dari 10 tahun akan lebih banyak menyediakan informasi akuntansi statutori, informasi akuntansi anggaran dan informasi tambahan yang digunakan untuk mengambil suatu keputusan, sehingga dapat dikatakan bahwa samakin lama umur UMKM berdiri maka akan semakin banyak pengalaman UMKM tersebut untuk 
menggunakan informasi akuntansi dalam proses pengambilan keputusan untuk menghadapi tantangan persaingan kedepan.

Kabupaten Jember merupakan Kabupaten yang jumlah UMKMnya terbesar pertama se-Jawa Timur dan jumlahnya terus meningkat. Data Badan Pusat Statistik menunjukan UMKM Kabupaten Jember berjumlah 181.147 unit yang bergerak diberbagai sektor dan mampu menyerap tenaga kerja. Pemerintah Kabupaten Jember dianggap berhasil mengembangkan sektor UMKM ditunjukan dengan diterimanya penghargaan Natamukti. Kecamatan di Kabupaten Jember yang memiliki unit UMKM terbanyak adalah Kecamatan Kaliwates dengan jumlah unit 17.950 UMKM. Berdasarkan survey pendahuluan pada beberapa UMKM di Kecamatan Kaliwates menunjukan bahwa pengetahuan akuntansi yang dimiliki para pelaku UMKM saat ini masih sebatas pemasukan dan pengeluaran kas serta usaha tersebut mendapat keuntungan atau kerugian, selain itu pelaku UMKM belum menggunakan informasi akuntansi. Sebagian besar, pelaku UMKM hanya menggunakan intuisi dalam pengambilan keputusan untuk berinvestasi.

\section{KAJIAN TEORI}

\section{Pengetahuan Akuntansi}

Menurut Prakoso (2018) pengetahuan akuntansi merupakan pengetahuan tentang ilmu akuntansi yang dimiliki oleh pelaku bisnis guna mengelola usahanya dan supaya dapat melakukan pembukuan laporan keuangan sesuai standar yang berlaku dari usaha yang dijalankan. Menurut Suryani (2016) pengetahuan akuntansi merupakan pengetahuan mengenai fakta transaksi bisnis dari suatu organsasi, pengetahuan tersebut mengenai klasifikasi yang meliputi jurnal dan buku besar serta pengetahuan tentang segala sesuatu tentang laporan keuangan baik laporan neraca, laba rugi, arus kas, perubahan modal maupun laporan keuangan untuk pihak manajemen perusahaan seperti laporan biaya produksi, anggaran dan sebagainya.

Menurut Abubakar \& Wibowo (2016) manfaat pengetahuan akuntansi bagi perusahaan yaitu: 1) pengetahuan besarnya modal yang dimiliki perusahaan; 2) mengetahui perkembangan atau maju mundurnya perusahaan; 3) sebagai dasar untuk perhitungan keuangan; 4) untuk menjelaskan keadaan perusahaan jika sewaktuwaktu memerlukan kredit dari bank atau pihak lain; 5) dasar untuk menentukan 
kebijakan yang akan ditempuh; 6) menarik minat investor saham jika perusahaan berbentuk perseroan terbatas.

Menurut Setyaningrum et al., (2013) indikator pengetahuan akuntansi menggunakan dua dimensi pengukuran yang biasanya digunakan dalam kajian audit, seperti: a) pengetahuan deklaratif, merupakan pengetahuan tentang fakta-fakta dan berdasarkan konsep, contohnya kas adalah bagian dari current assets; pengetahuan ini memudahkan dalam analisis rasio. Dimana pengetahuan deklaratif biasanya tergantung dari intruksi yang ada; b) pengetahuan prosedural, merupakan pengetahuan yang konsisten dengan aturan-aturan atau standar akuntansi yang berlaku, biasanya tergantung pada pengetahuan.

\section{Wirausaha}

Menurut Suryana (2017) wirausaha adalah seseorang yang menciptakan kesejahteraan untuk orang lain, menemukan cara-cara baru untuk menggunakan sumber daya, mengurangi pemborosan dan membuka lapangan kerja yang disenangi. Menurut Sjanbandhy (2015) wirausaha merupakan seseorang yang mengelola dan melembagakan usahanya sendiri. Faktor yang mendorong seseorang dalam mengambil keputusan berwirausaha dapat diketahui melalui penilaian kepribadian khususnya pengalaman dan latar belakangnya. Berdasarkan uraian tersebut dapat diartikan bahwa wirausaha merupakan seseorang yang menciptakan lapangan kerja untuk meciptakan kesejahteraan.

\section{Kepribadian Wirausaha}

Sari \& Dwirandra (2015) menyatakan bahwa kepribadian wirausaha merupakan kemampuan berinteraksi satu individu dengan individu lainnya, kemampuan untuk memulai terobosan yang baru, serta adanya keberanian untuk menanggung resiko membuka usaha saat ada peluang yang terbuka. Menurut Putra (2018) kepribadian wirausaha merupakan kemampuan mencapai persyaratan dalam berwirausaha yang efektif dalam suatu usaha atau bisnis. Kepribadian wirausaha merupakan keseluruhan cara seseorang untuk berinteraksi memberikan tanggapan yang positif terhadap peluang, berusaha dan secara kreatif menggunakan potensi-potensi diri untuk mengenali produk, mengelola dan menentukan cara berproduksi, menyusun operasi untuk pengadaan 
produk, memasarkan produk, serta mengatur permodalan operasi perusahaannya untuk memperoleh keuntungan bagi diri sendiri atau pelayanan yang lebih baik pada pelanggan dan masyarakat.

\section{Karakteristik Kepribadian Wirausaha}

Menurut Meredith (2015) ciri dan sifat yang menunjukan pribadi seorang wirausaha yaitu: a) percaya diri, wirausahaha adalah orang yang mempunyai rasa percaya diri sangat tinggi dan tidak meragukan kecakapan dan kemampuan dirinya. Mereka berpikir bahwa tidakan mereka akan mampu mengubah kejadian dan percaya bahwa mereka adalah pemimpin diri mereka sendiri; b) berorientasi tugas dan hasil, ini merupakan cara untuk mengukur sejauhmana seorang wirausaha mampu memusatkan perhatian pada hasil, bukan pada teknik dan proses yang digunakan dalam mencapai hasil.

Selanjutnya, c) pengambilan resiko, seorang wirausaha tidak takut menjalani pekerjaan yang disertai resiko dengan memperhitungkan besar kecilnya resiko. Dalam setiap kesempatan, wirausaha senantiasa menghindari resiko tinggi. Mereka menyadari bahwa prestasi yang lebih besar hanya mungkin dicapai jika mereka bersedia menerima resiko sebagai konsekuensi terwujudnya tujuan; d) kepemimpinan, merupakan suatu perilaku dengan tujuan tertentu untuk mempenagruhi aktivitas para anggota kelompok untuk mencapai tujuan bersama yang dirancang untuk memberikan manfaat individu dan organisasi; e) orientasi masa depan, wirausaha harus melakukan perencanaan dan berpikir kedepan. Mereka mencari dan mengantisipasi kemungkinan yang terjadi jauh dimasa depan.

\section{Umur Usaha}

Menurut Kristian (2018) umur usaha sangat menentukan cara berpikir, bertindak dan berperilaku bagi perusahaan dalam melaksanakan operasionalnya serta mengakibatkan perubahan pola pikir dan tingkat kedewasaan perusahaan dalam mengambil sikap atas setiap tindakan atau keputusannya. Begitu pula yang terjadi pada usaha kecil dan menengah. Jika seorang manajer usaha ingin melakukan sebuah perubahan atau peningkatan, maka harus mempunyai pola pikir yang luas berdasarkan 
pengetahuan dan pengalaman yang dimiliki oleh manajer dalam menentukan sebuah keputusan yang akan diterapkan terhadap perusahaan.

Holmes \& Nicholls (1989) memperlihatkan bahwa penyediaan informasi akuntansi dipengaruhi oleh usia usaha. Hasil penelitian itu menyatakan bahwa perusahaan yang berdiri selama 10 tahun atau kurang, menyediakan lebih banyak informasi akuntansi statutory, informasi akuntansi anggaran, informasi akuntansi tambahan untuk digunakan dalam pengambilan keputusan. Berbeda dengan perusahaan yang berdiri selama 11-20 tahun. Studi ini juga menyatakan bahwa semakin muda usia perusahaan, terdapat kecenderungan untuk menyatakan informasi akuntansi yang ekstensif untuk tujuan membuat keputusan yang dibandingkan dengan perusahaan yang lebih tua usianya.

Menurut Handayani \& Triyono (2016) umur dari suatu perusahaan berarti jangka waktu kegiatan perusahaan yang dihitung sejak perusahaan diresmikan atau berdiri berdasarkan akta pendirian. Berikut adalah persamaan dalam menghitung umur perusahaan:

\section{Umur perusahaan $=$ Tahun Observasi - Tahun berdiri}

\section{Informasi Akuntansi dalam Pengambilan Keputusan Investasi}

Harold \& Donnel (2016) pengambilan keputusan adalah pemilihan alternatif mengenai suatu cara bertindak yaitu inti dari perencanaan, suatu rencana tidak dapat dikatakan tidak ada jika ada keputusan, suatu sumber dapat dipercaya, petunjuk atau reputasi yang telah dibuat. Bayu (2014) informasi akuntansi berisi informasi masa lalu yang bermanfaat sebagai pelaporan informasi keuangan kepada pihak yang berkepentingan. Menurut Sari \& Dwirandra (2015) informasi akuntansi dalam pengambilan keputusan investasi merupakan informasi dalam berupa angka-angka yang berkaitan dengan entitas ekonomi yang berguna di dalam pengambilan keputusan ekonomi untuk menentukan pilihan yang tepat diantara banyak alternatif tindakan. Menurut Putra \& Arizona (2016) penggunaan informasi akuntansi dalam sebuah usaha sangat berpengaruh bagi kelangsungan usaha tersebut terutama dalam pengambilan keputusan investasi, pengambilan keputusan investasi juga memiliki peran sangat penting bagi kelangsungan usaha yang dimiliki oleh seseorang. 


\section{Peran Informasi Akuntansi dalam Pengambilan Keputusan}

Menurut Riduwan (2015) dalam pengambilan keputusan, informasi akuntansi memiliki peran sebagai berikut: 1) informasi akuntansi sebagai perangsang pendefinisian masalah; 2) pemisah alternatif tindakan yang satu dengan tindakan alternatif lain; 3) penjelas konsekuensi berbagai alternatif tindakan yang akan dipilih; 4) membantu menganalisis dan menilai berbagai alternatif tindakan yang akan dipilih. Informasi akuntansi dimasukan sebagai input ke dalam model pengambilan keputusan ditentukan oleh berbagai faktor berikut yaitu: a) informasi akuntansi dianggap relevan dengan tipe keputusan yang dibuat oleh penggambil keputusan; b) relevansi informasi akuntansi sangat ditentukan oleh persepsi pengambilan keputusan terhadap akuntansi; c) tipe pengambilan keputusan berasal dari intern perusahaan yang mengambil keputusan mengenai operasi dan sistem akuntansi yang digunakan untuk mengambil keputusan.

\section{Pengaruh Pengetahuan Akuntansi terhadap Penggunaan Informasi Akuntansi dalam Pengambilan Keputusan Investasi}

Menurut Astiani \& Sugoro (2017) salah satu permasalahan yang masih dihadapi UMKM adalah dalam menyelenggarakan dan memanfaatkan informasi akuntansi dalam pengelolaan usahanya. Jika dilihat dari segi pertumbuhannya, usaha kecil mengalami masalah yang timbul pada tahap-tahap yang serupa, ini disebabkan perusahaan tidak memiliki informasi, baik dari dalam usaha maupun dari luar usaha. Salah satu sistem informasi memberikan informasi yang dibutuhkan adalah sistem informasi akuntansi. Ketidakmampuan dalam bidang akuntansi menjadi faktor utama yang menimbulkan masalah dan mengakibatkan kegagalan perusahaan kecil dan menengah dalam membangun usaha.

Pencatatan keuangan secara akuntansi dianggap terlalu rumit untuk dilakukan dalam berskala kecil seperti UMKM karena siklus usaha pada UMKM yang sederhana. Hal ini menunjukan bahwa perlu adanya dorongan bagi pelaku UMKM untuk menggunakan bisnis informasi akuntansi dengan dilakukan pemetaan pengetahuan yang mereka miliki. Pengetahuan akuntansi yang baik akan menjadikan para pelaku bisnis UMKM mampu memahami serta memanfaatkan informasi akuntansi sehingga dapat dipergunakan dalam pembuatan keputusan investasi (Juniariani \& Wirakusuma, 2016). 


\section{Pengaruh Kepribadian Berwirausaha terhadap Penggunaan Informasi Akuntansi dalam Pengambilan Keputusan Investasi}

Menurut Handar (2017) pemberdayaan UMKM sangat penting dilakukan sebagai upaya mendorong pengembangan jiwa kewirausahaan masyarakat. Majumundur serta berkembangnya UMKM adalah mutlak karena keinginan dan motivasi dari masyarakat sebagai pelaku usaha tersebut dengan mengubah pola berfikir usaha dari sekedar menutupi kebutuhan berubah menjadi seorang wirausaha atau entrepreneur. Pelaku UMKM yang memiliki kepribadian wirausaha yang baik akan dapat lebih mempertahankan bisnisnya dan dapat menjadi inspirasi masyarakat lain untuk menjadi wirausaha yang tangguh.

Wirausaha yang memiliki kepribadian baik cenderung melakukan persaingan bisnis dengan cara yang berbeda termasuk dalam penggunaan informasi akuntansi dengan tujuan pengambilan keputusan investasi, cara pandang wirausaha yang berkepribadian baik lebih prospektif dalam mengembangkan usaha. Seseorang yang memiliki kepribadian kewirausahaan yang baik maka akan mampu meningkatkan kepemimpinannya dalam mengambil resiko dan pengambilan keputusan serta meningkatkan kinerja manajerialnya.

\section{Pengaruh Umur Usaha terhadap Penggunaan Informasi Akuntansi dalam \\ Pengambilan Keputusan Investasi}

Menurut Asih (2018) umur perusahaan merupakan berapa lamanya perusahaan yang dimaksud berdiri dan beroperasi, semakin lama suatu perusahaan beroperasi maka kebutuhan akan suatu informasi akan semakin kompleks. Hal ini disebabkan oleh tuntutan dari perkembangan yang dialami oleh perusahaan. Umur perusahaan juga akan mempengaruhi tingkat penggunaan informasi akuntansi pada suatu usaha yang didirikan, perusahaan yang memiliki usia lebih dari 10 tahun akan lebih banyak menyediakan informasi akuntansi statutori, informasi akuntansi anggaran dan informasi tambahan yang digunakan untuk mengambil suatu keputusan. Hal tersebut dapat diartikan bahwa samakin lama umur UMKM berdiri maka akan semakin banyak pengalaman UMKM tersebut untuk menggunakan informasi akuntansi dalam proses pengambilan keputusan untuk menghadapi tantangan persaingan kedepan. 


\section{METODE PENELITIAN}

Penelitian ini termasuk dalam explanatory research. Penelitian ini mencari hubungan antara variabel pengetahuan akuntansi dan kepribadian wirausaha terhadap penggunaan informasi akuntansi dalam pengambilan keputusan pada UMKM di Kabupaten Jember. Penelitian ini merupakan penelitian kuantitatif yaitu data yang berbentuk angka atau data kualitatif yang diangkakan. Sedangkan sumber data dalam penelitian ini terdiri dari data primer dan data sekunder. Data primer berupa karakteristik responden dan hasil jawaban responden terhadap kuesioner. Sedangkan data sekunder berupa jumlah UMKM di Kabupaten Jember dan jumlah UMKM di Kecamatan Kaliwates.

Populasi dalam penelititian ini adalah pelaku UMKM di Kecamatan Kaliwates yang berjumlah 17.950. Teknik pengambilan sampel dilakukan dengan teknik convenience sampling yaitu pengambilan sampel didasarkan pada ketersediaan elemen dan kemudahan untuk mendapatkannya. Untuk menentukan sampel dari populasi yang ditetapkan, penelitian ini menggunakan teknik Slovin hingga diperoleh 100 responden. Teknik pengumpulan data yang akan digunakan dalam penelitian ini adalah dengan menggunakan angket yang berisi kuesioner yang akan diberikan secara langsung kepada responden dan kemudian responden akan mengisinya sesuai dengan pendapat dan persepsi responden. Metode analisis data yang digunakan dalam penelitian ini yaitu analisis regresi linier berganda.

Definisi operasional variabel yang digunakan sebagai instrument dalam penelitian adalah sebagai berikut: 1) pengetahuan akuntansi $\left(\mathrm{X}_{1}\right)$ merupakan ilmu pencatatan, penggolongan, peringkasan dan penganalisaan transaksi keuangan pada UMKM. Variabel pengetahuan akuntansi menggunakan indikator yang digunakan Setyaningrum et. al., (2013) yaitu: a) pengetahuan deklaratif yaitu pengetahuan pelaku UMKM tentang fakta-fakta dan berdasarkan konsep; b) pengetahuan procedural yaitu pengetahuan yang konsisten dengan aturan-aturan atau standar akuntansi yang berlaku pada UMKM; 2) kepribadian wirausaha $\left(\mathrm{X}_{2}\right)$ merupakan sifat yang dimiliki pelaku UMKM untuk menciptakan sesuatu yang baru dan berbeda serta berani mengambil resiko dalam berbagai kesempatan. Variabel pengetahuan akuntansi menggunakan indikator yang digunakan oleh Meredith (2015), diantaranya yaitu: a) percaya diri, yaitu pelaku UMKM tidak meragukan kemampuan dirinya; b) berorientasi pada tugas dan 
hasil, yaitu pelaku UMKM mampu memusatkan perhatian pada hasil, bukan pada teknik dan proses yang digunakan untuk mencapai hasil tersebut; c) pengambilan resiko yaitu pelaku UMKM mampu menjalani pekerjaan yang disertai resiko dengan memperhitungkan besar kecilnya resiko; d) kepemimpinan yaitu pelaku UMKM mampu mempengaruhi orang lain untuk mencapai tujuan dalam melakukan kegiatan bisnis; e) orientasi masa depan yaitu pelaku UMKM melakukan perencanaan untuk mengantisipasi kemungkinan yang terjadi jauh dimasa depan.

Selanjutnya, 3) umur usaha $\left(\mathrm{X}_{3}\right)$ merupakan lama berdirinya UMKM yang dimiliki oleh pelaku usaha. Variabel umur usaha menggunakan alat ukur yang diungkapkan Handayani \& Triyono (2016) yaitu tahun observasi dikurangi tahun berdirinya UMKM; 4) informasi akuntansi dalam pengambilan keputusan investasi (Y) merupakan tindakan pelaku UMKM untuk menggunakan informasi keuangan untuk pengambilan keputusan. Menurut Riduwan (2105) variabel informasi akuntansi dalam pengambilan keputusan investasi menggunakan indikator, yaitu; a) pelaku UMKM memiliki anggapan bahwa informasi akuntansi dianggap relevan untuk pengambilan keputusan investasi; b) pelaku UMKM memiliki anggapan bahwa relevansi informasi akuntansi sangat ditentukan oleh persepsi pengambilan keputusan investasi; c) pelaku UMKM mempu mengambil keputusan mengenai sistem akuntansi yang digunakan untuk mengambil keputusan investasi

\section{HASIL PENELITIAN}

\section{Analisis Data}

\section{Statistik Deskriptif Karakteristik Responden}

Karakteristik Responden dalam penelitian ini meliputi jenis kelamin dan usia responden. Hasil penelitian menunjukan karakteristik responden sebagai berikut:

Tabel 1.

Karakteristik Responden

\begin{tabular}{|c|c|c|c|c|c|c|}
\hline No & Kriteria & Jumlah & Persentase & Mean & Modus & Median \\
\hline \multirow[t]{3}{*}{1.} & Jenis Kelamin & & & & & \\
\hline & - Laki-Laki & 57 & $57 \%$ & & & \\
\hline & - Perempuan & 43 & $43 \%$ & & & \\
\hline \multirow[t]{4}{*}{2.} & Usia & & & 45,59 & 56 & 45 \\
\hline & - $30-40$ tahun & 33 & $33 \%$ & & & \\
\hline & - 41 - 50 tahun & 37 & $37 \%$ & & & \\
\hline & - Lebih dari 50 tahun & 30 & $30 \%$ & & & \\
\hline
\end{tabular}

(Sumber: Data Primer Diolah, 2019) 
Berdasarkan tabel 1, dapat diketahui bahwa berdasarkan karakteristik jenis kelamin, jumlah responden perempuan lebih banyak daripada laki-laki. Sedangkan berdasarkan karakteristik usia, responden terbanyak merupakan responden dengan rentang usia antara 41 hingga 50 tahun. Hal ini menunjukan bahwa pemilik UMKM di wilayah Kaliwates Kabupaten Jember mayoritas merupakan laki-laki dengan rentang usia yang memasuki usia tidak produktif dikarenakan pada rentang usia tersebut mayoritas pekerja laki-laki ataupun perempuan sudah tidak dimanfaatkan oleh perusahaan swasta sehingga memilih untuk berwirausaha dengan mendirikan UMKM guna memenuhi kebutuhan sehari-hari.

\section{Analisis Regresi Linier Berganda}

Metode analisis data yang digunakan dalam penelitian ini yaitu analisis regresi linier berganda. Analisis ini bertujuan untuk mengetahui hubungan antara variabel pengetahuan akuntansi $\left(\mathrm{X}_{1}\right)$, kepribadian wirausaha $\left(\mathrm{X}_{2}\right)$ dan umur usaha $\left(\mathrm{X}_{3}\right)$ terhadap penggunaan informasi akuntansi dalam pengambilan keputusan investasi (Y) pada pelaku UMKM di Kecamatan Kaliwates Kabupaten Jember. Hasil analsis regresi linier berganda disajikan pada tabel 2 berikut:

Tabel 2.

Hasil Analisis Regresi Linier Berganda

\begin{tabular}{ccccccc}
\hline \multirow{2}{*}{ Model } & \multicolumn{2}{c}{ Unstandardized Coefficients } & Standardized Coefficients & t & \multirow{2}{*}{ Sig. } \\
\cline { 2 - 5 } & B & Std. Error & Beta & & \\
\hline \multirow{2}{*}{1} & (Constant) & 1,797 & 0,665 & 0,646 & 12,346 & 0,008 \\
\cline { 2 - 5 } & 0,636 & 0,052 & 0,113 & 0,000 \\
& X1 & 0,112 & 0,043 & 0,260 & 2,594 & 0,011 \\
& X2 & 0,042 & & 5,833 & 0,000 \\
\hline
\end{tabular}

(Sumber: Data Primer Diolah, 2019)

Berdasarkan tabel 2, maka model regresi model regresi yang dihasilkan sebagai model penjelas pengaruh pengetahuan akuntansi $\left(X_{1}\right)$, kepribadian wirausaha $\left(X_{2}\right)$ dan umur usaha $\left(\mathrm{X}_{3}\right)$ terhadap penggunaan informasi akuntansi dalam pengambilan keputusan investasi (Y) pada UMKM di Kecamatan Kaliwates Kabupaten Jember dapat dinyatakan sebagai berikut:

$$
\mathrm{Y}=1,797+0,636 \mathrm{X}_{1}+0,112 \mathrm{X}_{2}+0,247 \mathrm{X}_{3}+e
$$

Persamaan regresi linier berganda tersebut dapat menjelaskan beberapa hal berikut: a) konstanta dalam persamaan regresi tersebut adalah 1,797 yang berarti jika 
pengetahuan akuntansi $\left(\mathrm{X}_{1}\right)$, kepribadian wirausaha $\left(\mathrm{X}_{2}\right)$ dan umur usaha $\left(\mathrm{X}_{3}\right)$ bernilai 0 , maka penggunaan informasi akuntansi dalam pengambilan keputusan investasi ( $\mathrm{Y}$ ) sebesar 1,797 ; b) nilai koefisien regresi variabel pengetahuan akuntansi $\left(\mathrm{X}_{1}\right)$ sebesar 0,636 yang berarti jika terjadi peningkatan variabel pengetahuan akuntansi $\left(\mathrm{X}_{1}\right)$ makaanilai variabel penggunaan informasi akuntansi dalam pengambilan keputusan investasi (Y) akan mengalami peningkatan sebesar 0,636 ; c) nilai koefisien regresi variabel kepribadian wirausaha $\left(\mathrm{X}_{2}\right)$ sebesar 0,112 yang berarti jika terjadi peningkatan variabel kepribadian wirausaha $\left(\mathrm{X}_{2}\right)$ maka nilai variabel penggunaan informasi akuntansi dalam pengambilan keputusan investasi (Y) akan mengalami peningkatan sebesar 0,112 ; d) nilai koefisien regresi variabel umur usaha $\left(\mathrm{X}_{3}\right)$ sebesar 0,247 yang berarti jika terjadi peningkatan variabel umur usaha $\left(\mathrm{X}_{3}\right)$ maka nilai variabel penggunaan informasi akuntansi dalam pengambilan keputusan investasi (Y) akan mengalami peningkatan sebesar 0,247.

\section{Uji t}

Uji t-test digunakan untuk menguji seberapa jauh pengaruh variabel independen yang digunakan dalam penelitian secara individual dalama menerangkan variabel dependen secara parsial. Pengujian dilakukan dengan menggunakan signifikansi level $0,05(5 \%)$ dengan dasar pengambilan keputusan yaitu jika nilai signifikansi kurang dari 0,05 maka $\mathrm{H}_{0}$ ditolak maka $\mathrm{H}_{\mathrm{a}}$ diterima berarti ada pengaruh signifikan variabel independen secara individu terhadap variabel dan demikian pula sebaliknya. Hasil uji t disajikan pada tabel 3 berikut.

Tabel 3.

Hasil Uji t

\begin{tabular}{lcc}
\hline \multicolumn{1}{c}{ Variabel } & Sig. & Keterangan \\
\hline Pengetahuan Akuntansi $\left(\mathrm{X}_{1}\right)$ & 0,000 & $\mathrm{H}_{0}$ ditolak \\
Kepribadian Wirausaha $\left(\mathrm{X}_{2}\right)$ & 0,011 & $\mathrm{H}_{0}$ ditolak \\
Umur Usaha $\left(\mathrm{X}_{3}\right)$ & 0,000 & $\mathrm{H}_{0}$ ditolak \\
\hline
\end{tabular}

(Sumber: Data Primer Diolah, 2019)

Berdasarkan tabel 3, dapat diketahui besar dari pengaruh masing-masing variabel independen terhadap variabel dependen sebagai berikut: 1) pengetahuan akuntansi terhadap penggunaan informasi akuntansi dalam pengambilan keputusan investasi, hasil pengujian pengaruh antara variabel pengetahuan akuntansi terhadap 
penggunaan informasi akuntansi dalam pengambilan keputusan investasi menunjukkan bahwa apengetahuan akuntansi berpengaruh signifikan terhadap penggunaan informasi akuntansi dalam pengambilan keputusan investasi pada UMKM Kecamatan Kaliwates Kabupaten Jember; 2) kepribadian wirausaha terhadap penggunaan informasi akuntansi dalam pengambilan keputusan investasi hasil pengujian pengaruh antara variabel kepribadian wirausaha terhadap penggunaan informasi akuntansi dalam pengambilan keputusan investasi menunjukkan bahwa kepribadian wirausaha berpengaruh signifikan terhadap penggunaan informasi akuntansi dalam pengambilan keputusan investasi pada UMKM Kecamatan Kaliwates Kabupaten Jember.

Selanjutnya, 3) umur usaha terhadap penggunaan informasi akuntansi dalam pengambilan keputusan investasi hasil pengujian pengaruh antara variabel umur usaha terhadap penggunaan informasi akuntansi dalam pengambilan keputusan investasi menunjukkan bahwa umur usaha berpengaruh signifikan terhadap penggunaan informasi akuntansi dalam pengambilan keputusan investasi pada UMKM Kecamatan Kaliwates Kabupaten Jember.

\section{Koefisien Determinasi}

Koefisien determinasi bertujuan untuk mengukur seberapa jauh kemampuan model dalam menerangkan variasi variabel dependen. Penelitian ini berpatokan pada nilai adjusted $R$ square atau koefisien determinasi yang sudah disesuaikan dengan dasar pengambilan keputusan digunakan kriteria yaitu apabila $\mathrm{R}^{2}$ benilai negatif (-) maka dapat diartikan bahwa tidak terdapat pengaruh $\mathrm{X}$ terhadap $\mathrm{Y}$. Semakin kecil nilai koefisien determinasi $\left(\mathrm{R}^{2}\right)$ maka pengaruh variabel bebas terhadap variabel terikat semakin lemah, jika $\mathrm{R}^{2}$ semakin mendekati 1, maka pengaruh tersebut semakin kuat.

Tabel 4.

Hasil Koefisien Determinasi

\begin{tabular}{ccccc}
\hline Model & R & R Square & Adjusted R Square & Std. Error of the Estimate \\
\hline 1 & 0,974 & 0,948 & 0,947 & 1,87777 \\
\hline
\end{tabular}
(Sumber: Data Primer Diolah, 2019)

Berdasarkan tabel 4, dapat diketahui bahwa hasil koefisien determinasi pada variabel pengetahuan akuntansi $\left(\mathrm{X}_{1}\right)$, kepribadian wirausaha $\left(\mathrm{X}_{2}\right)$ dan umur usaha $\left(\mathrm{X}_{3}\right)$ memperoleh nilai adjusted $R$ Square sebesar 0,947 yang berarti bahwa pengaruh variabel pengetahuan akuntansi $\left(X_{1}\right)$, kepribadian wirausaha $\left(X_{2}\right)$ dan umur usaha $\left(X_{3}\right)$ 
terhadap penggunaan informasi akuntansi dalam pengambilan keputusan investasi sebesar 94,7\% sedangkan sisanya yaitu 5,3\% dipengaruhi oleh variabel lain yang tidak digunakan dalam penelitian ini.

\section{PEMBAHASAN}

\section{Pengaruh Pengetahuan Akuntansi terhadap Penggunaan Informasi Akuntansi dalam Pengambilan Keputusan Investasi}

Pengetahuan akuntansi berpengaruh terhadap penggunaan informasi akuntansi dalam pengambilan keputusan pada UMKM di Kecamatan Kaliwates Kabupaten Jember dibuktikan dengan hasil uji $\mathrm{t}$ yang menunjukan bahwa semakin baik pengetahuan akuntansi maka penggunaan informasi akuntansi dalam pengambilan keputusan investasi akan meningkat. Temuan dari penelitian ini sesuai dengan pendapat yang dikemukakan oleh Astiani \& Sugoro (2017) salah satu permasalahan yang masih dihadapi UMKM adalah permasalahan dalam menyelenggarakan dan memanfaatkan informasi akuntansi dalam pengelolaan usahanya. Salah satu sistem informasi memberikan informasi yang dibutuhkan adalah sistem informasi akuntansi.

Ketidakmampuan dalam bidang akuntansi menjadi faktor utama yang menimbulkan masalah dan mengakibatkan kegagalan perusahaan kecil dan menengah dalam membangun usaha. Hal ini memberikan indikasi bahwa perusahaan dalam melaporkan keuangan berdasarkan kebutuhannya saja dan perusahaan cenderung tidak melaporkan secara kontinyu. Pencatatan keuangan secara akuntansi dianggap terlalu rumit untuk dilakukan dalam ukuran skala kecil seperti UMKM karena siklus usaha pada UMKM yang sederhana.

Hasil penelitian ini sejalan dengan penelitian yang dilakukan oleh Sari \& Dwiandra (2015), Juniariani \& Wirakusuma (2016), Putra \& Arozona (2016) serta Setyaningrum et al., (2013) yang menunjukan bahwa pengetahuan akuntansi berpengaruh positif signifikan terhadap penggunaan informasi akuntansi dalam pengambilan keputusan investasi. Hasil penelitian ini menunjukan bahwa jika seorang pemilik UMKM mengerti serta memahami tentang fungsi serta manfaat dari informasi akuntansi maka akan mendorong pemilik UMKM untuk menggunakan informasi akuntansi sebagai acuan pengambilan keputusan investasi. 


\section{Pengaruh Kepribadian Wirausaha terhadap Penggunaan Informasi Akuntansi dalam Pengambilan Keputusan Investasi}

Kepribadian wirausaha berpengaruh terhadap penggunaan informasi akuntansi dalam pengambilan keputusan pada UMKM di Kecamatan Kaliwates Kabupaten Jember dibuktikan dengan hasil uji t yang bahwa semakin baik kepribadian wirausaha maka penggunaan informasi akuntansi dalam pengambilan keputusan investasi akan meningkat.

Temuan dari penelitianaini sesuai dengan pendapat yang dikemukakan oleh Putra (2018) kepribadian kewirausahaan merupakan kemampuan seseorang untuk mencapai persyaratan dalam berwirausaha yang efektif dalam suatu usaha ataupun bisnis. Sikap dan perilaku seorang wirausaha juga berperan penting untuk perusahaan dalam berbagai skala usaha untuk mecapai keberhasilan dalam lingkungan yang kompetitif. Wirausaha yang memiliki kepribadian baik cenderung melakukan persaingan bisnis dengan cara yang berbeda termasuk dalam penggunaan informasi akuntansi dengan tujuan pengambilan keputusan investasi, cara pandang wirausaha yang berkepribadian baik lebih prospektif dalam mengembangkan usaha.

Seseorang yang memiliki kepribadian kewirausahaan yang baik maka akan mampu meningkatkan kepemimpinannya dalam mengambil resiko dan pengambilan keputusan serta meningkatkan kinerja manajerialnya. Maisaroh (2018) menyatakan bahwa kepribadian berwirausaha dipengaruhi oleh beberapa faktor salah satunya adalah pengalaman hidup yang dijalani seseorang. Semakin banyak aktifitas atau pengalaman seseorang dalam berorganisasi dan semakin tinggi pengalaman kerja maka kepribadian berwirausaha pada sektor UMKM akan semakin tinggi.

Hasil penelitian ini sejalan dengan penelitian yang dilakukan oleh Sari \& Dwiandra (2015), Juniariani \& Wirakusuma (2016) serta Putra \& Arozona (2016) yang menunjukan bahwa kepribadian wirausaha berpengaruh signifikan terhadap penggunaan informasi akuntansi dalam pengambilan keputusan investasi. Hasil penelitian ini menunjukan bahwa jika seseorang memiliki jiwa kewirausahaan yang tinggi maka akan cenderung menggunakan informasi akuntansi dalam membuat keputusan investasi. Begitupula jika seseorang tidak memiliki jiwa kewiarusahaan yang baik maka cenderung tiak akan menggunakan informasi akuntansi dalam membuat keputusan investasi. 


\section{Pengaruh Umur Usaha terhadap Penggunaan Informasi Akuntansi dalam Pengambilan Keputusan Investasi}

Umur usaha berpengaruh terhadap penggunaan informasi akuntansi dalam pengambilan keputusan pada UMKM di Kecamatan Kaliwates Kabupaten Jember dibuktikan dengan hasil uji t yang menunjukan bahwa semakin lama suatu usaha berdiri maka penggunaan informasi akuntansi dalam pengambilan keputusan investasi akan meningkat.

Menurut Asih (2018) umur perusahaan merupakan berapa lamanya perusahaan yang dimaksud berdiri dan beroperasi, semakin lama suatu perusahaan beroperasi maka kebutuhan akan suatu informasi akan semakin kompleks. Hal ini disebabkan oleh tuntutan dari perkembangan yang dialami oleh perusahaan. Umur perusahaan juga akan mempengaruhi tingkat penggunaan informasi akuntansi pada suatu usaha yang didirikan, perusahaan yang memiliki usia lebih dari 10 tahun akan lebih banyak menyediakan informasi akuntansi statutori, informasi akuntansi anggaran, dan informasi tambahan yang digunakan untuk mengambil suatu keputusan. Sehingga dapat dikatakan bahwa samakin lama umur UMKM berdiri maka akan semakin banyak pengalaman UMKM tersebut untuk menggunakan informasi akuntansi dalam proses pengambilan keputusan untuk menghadapi tantangan persaingan kedepan.

Hasil penelitian ini sejalan dengan penelitian yang dilakukan oleh Kristian (2010) dan Setyaningrum et al., (2013) yang menunjukan bahwa umur usaha berpengaruh signifikan terhadap penggunaan informasi akuntansi dalam pengambilan keputusan investasi. Perusahaan yang berdiri kurang dari 10 tahun cenderung lebih sedikit menggunakan informasi akuntansi karena pengalaman yang masih sedikit. Sedangkan usaha yang telah berdiri lebih dari 10 tahun cenderung lebih banyak memanfaatkan informasi akuntansi untuk mengambil keputusan investasi. Umur usaha menentukan cara berpikir, bertindak dan berperilaku pemilik usaha dalam melaksanakan operasionalnya serta mengakibatkan pemilik usaha merubah pola pikirnya dan tingkat kedewasaan usaha dalam mengambil keputusan serta tindakan untuk menentukan keputusan investasi. 


\section{SIMPULAN}

Pengetahuan akuntansi, kepribadian wirausaha dan umur usaha berpengaruh terhadap penggunaan informasi akuntansi dalam pengambilan keputusan investasi pada UMKM di Kabupaten Kaliwates Jember. Hal ini menunjukkan bahwa semakin baik penerapan variabel-variabel tersebut, maka penggunaan informasi akuntansi dalam pengambilan keputusan investasi akan semakin meningkat.

\section{DAFTAR PUSTAKA}

Abubakar, A., \& Wibowo, W. (2016). Akuntansi untuk Bisnis: Usaha Kecil dan Menengah. Jakarta: Gramedia Widiasarana Indonesia

Asih, R. (2018). Faktor-Faktor yang Mempengaruhi Usaha Kecil dan Menengah (UKM) dalam Menggunakan Informasi Akuntansi (Studi pada Usaha Kecil dan Menengah (UKM) Industri Meubel di Kecamatan Ngemplak Kabupaten Boyolali. Skripsi. IAIN Surakarta

Astiani, Y \& Sugoro, E. M. (2017). Pengaruh Persepsi Pelaku Usaha Mikro Kecil dan Menengah tentang Akuntansi, Pengetahuan Akuntansi dan Skala Usaha terhadap Penggunaan Informasi Akuntansi. Jurnal Fakultas Ekonomi, 6(2), 1-15

Bank Indonesia \& Lembaga Pengembangan Perbankan Indonesia (LPPI). (2015). Profil Bisnis Usaha Mikro, Kecil dan Menengah (UMKM). Diakses dari https://www.bi.go.id/id/umkm/penelitian/nasional/kajian/Documents/Profil\%20 Bisnis\%20UMKM.pdf

Bayu, B. (2014). Pengantar Akuntansi Manajemen. Jakarta: Aksara Media

Handar, H. (2018). Menumbuhkan Jiwa Kewirausahaan Pelaku UMKM. Diakses dari http://upeks.fajar.co.id/2017/04/10/menumbuhkan-jiwa-kewirausahaan-pelakuumkm/

Handayani, S., \& Triyono, T. (2016). Analisis Pengaruh Ukuran Perusahaan, Umur Perusahaan, Kinerja Perusahaan, Likuiditas dan Leverage terhadap Kualitas Akrual (Studi Empiris pada Perusahaan Manufaktur yang Terdaftar di Bursa Efek Indonesia Periode 2010-2014). Skripsi. Universitas Muhammadiyah Surakarta

Harold, K., \& Donnel, C. (2016). Manajemen Dasar, Edisi Kedua, Cetakan Ketujuh. Jakarta: Bumi Aksara

Holmes, S., \& Nicholls, N. 1989. An Analysis of the Use of Accounting Information by Australian Small Busines. Journal of Small Business Management, 26(20),57-68

Juniariani, N. M. R., \& Wirakusuma, M. G. (2016). Pengaruh Pengetahuan Akuntansi dan Jiwa Kewirausahaan pada Penggunaan Informasi Akuntansi dalam Pembuatan Keputusan Investasi. Jurnal Universitas Udayana, 21(2), 115-232

Kristian, C. (2018). Pengaruh Skala Usaha, Umur Perusahaan, Pendidikan Pemilik terhadap Penggunaan Informasi Akuntansi pada Usaha Kecil Menengah di Kabupaten Blora. Skripsi. UniversitasaNegeri Semarang 
Maisaroh, M. (2018). Kajian Karakteristik Kewirausahaan terhadap Keberhasilan Usaha UKM (Studi Kasus Sentra Industri Konveksi Dusun Mlangi dan Sawahan Nogotirto Gamping Sleman Yogyakarta. Jurnal Semnas dan Call for Paper $S C A, 8(1), 1-9$

Meredith, G. (2015). Kewirausahaan Teori dan Praktek, Jakarta: PT Pustaka Binaman Presindo

Prakoso, Y. A. (2018). Pengaruh Latar Belakang Pendidikan, Pengetahuan Akuntansi Pemilik dan Ukuran Usaha Kecil Menengah (UKM) terhadap Penerapan SAKETAP di Kota Semarang. Artikel Ilmiah. Universitas Muhammadiyah Semarang

Putra, I. P. M. J. S., \& Arizona, I. P. E. (2016). Pengaruh Pengetahuan Akuntansi dan Jiwa Kewirausahaan terhadap Penggunaan Informasi Akuntansi dalam Pengambilan Keputusan Investasi. Prosiding Seminar Nasional Hasil Penelitian dan Pengabdian kepada Masyarakat. Universitas Mahasaraswati Denpasar

Putra, J. W. (2018). Pengaruh Penggunaan Sistem Akuntansi Manajemen dan Kepribadian Kewirausahaan terhadap Kinerja Manajerial di Koperasi Tani Sejahtera Trenggalek. Skripsi. Universitas Nusantara PGRI Kediri

Riduwan, R. (2015). Dasar-Dasar Statistika. Bandung: Alfabeta

Sari, N. M. A. M., \& Dwirandra, A. A. N. B. (2015). Pengaruh Kepribadian Wirausaha dan pengetahuan Akuntansi pada Penggunaan Informasi Akuntansi dalam Pembuatan Keputusan Investasi. E-Jurnal Akuntansi Universitas Udayana, 11(1), 303-319

Setyaningrum, D., Wiranto, A., \& Sukirman, S. (2013). Pengaruh Pendidikan Pemilik, Pengetahuan Akuntansi Pemilik, Budaya Perusahaan dan Umur Usaha terhadap Penggunaan Informasi Akuntansi pada UKM dengan Ketidakpastian Lingkungan sebagai Variabel Pemoderasi (Studi empiris terhadap UKM yang Menghasilkan Produk Unggulan di Kabupaten Banyumas). Jurnal Universitas Jendral Soedirman,4(1), 529-543

Sjanbandhy, S. (2015). Pengembangan Kualitas SDM dari Perspektif PIO. Depok: UI Press

Suryana, S. (2017). Kewirausahaan Pedoman Prkatis: Kiat dan Proses Menuju Sukses. Jakarta: Salemba Karya

Suryani, E. (2016). Pengaruh Pengetahuan Akuntansi dan Pemanfaatan Software Akuntansi terhadap Kinerja Individu Mahasiswa Jurusan Akuntansi STIE Perbanas. Skripsi. STIE Perbanas Surabaya

Susanto, A. (2017). Sistem Informasi Akuntansi, Cetakan Pertama. Bandung: Lingga Jaya 